\title{
Moral and Manners of Flappers (New Woman) In F. Scott Fitzgerald Works
}

\author{
Henny Suharyati ${ }^{*}$ \\ ${ }^{*}$ Universitas Pakuan, Bogor, Indonesia \\ Corresponding Author: henny.suharyati@unpak.ac.id
}

\begin{abstract}
Flapper's phenomenon appeared in the 1920s in line with the feminist achievement on women's suffrage. Industrialism opened the possibility for vistas of young American generations at that time to undergo a good member of changes both in moral and manners. The characteristics of flappers are reflected in literary works by Fitzgerald, an American famous novelist. In achieving the objective of this research, a qualitative method is applied by the way of library research - collecting data from both primary and secondary sources. The former, This Side of Paradise (1919), a novel telling about the young generation, The Great Gatsby (1925) and Tender is The Night, both describing the maturity of the flappers. The outcome of the research proves that there is a similarity, in moral and manners, between the flappers in Fitzgerald's fictions and those in reality during the 1920s. The new values differed from the old ones which were maintained by the cult of true womanhood, especially in concern with those young generations performances, manners, and morals. The media encouraged the development of the new values. There is also a sense of paradox: on one hand Fitzgerald implicitly tended to spread out the moral and manners of flappers, but on the other hand, he criticizes them.
\end{abstract}

Keywords: Moral and manners, flappers (new woman), 1920s.

\section{INTRODUCTION}

In the history of the development of American women, there is a myth of position women who are known as true worship of values femininity that emerged in the ninth century. Myth "the cult of true womanhood "(true worship of feminine values) is also known with the title Victorian traditions. Myth puts women as "hostage in the home". In this case, the woman must be at home, she must have characteristics that characterize typically: "pious, pure, submissive, and loyally domestic" (pious, holy, resigned and really attach importance to the family). To support the characteristic above, the appearance of a woman is limited, for example, she must dress polite and did not show his body: his long dress was over heels with tight corsets and long hairs bun. Then the activity they are limited only to matters of necessity household only. If these values are ignored then women will be cornered by the judgment of the people who directly sentence it as women who are not good and not virtuous.

In addition, women's space is limited. Women are considered weak and need protection from men. Therefore the role women only deal with problems that deal with home stairs only. While the men are strong and responsible will tackle issues related to society. The situation causing women not to have the opportunity to move forward and grow. this also causes women not to have the right to vote and selected, the right to education and the same inheritance as men.

The position and role of women who have been disaggregated gave rise to values called "the true womanhood" or "the cult of domesticity". According to P. Ryan, a social observer and woman, the "cult of domesticity" distinguishes the role of women socially. Men's affairs are more dominant outside the home, while women are enough to take care of the family. "The cult of true womanhood" is a cultural expression of women who have the stereotypical values of Victorian times. Barbara Welter, historian, argues that women judge themselves or are judged by society. $\mathrm{He}$ must have certain value characteristics such as: "virtues, piety, purity, submissiveness and domesticity (pious, holy, virgin, resigned, and concerned with his family)." (Levine \& Middlekauff, ed., 1972: 145).

In the $1920 \mathrm{~s}$ women's movements were intensified, even this year called the transition because at that time women really wanted to eliminate discrimination in equal rights. Each state in America imposes legal discrimination on women. Lois W. Banner mentions that there are fourteen of the forty-six states that start giving equal rights to inheritance, and guardianship to women. Many states also do not give elected rights (in the political field) to women. Although there are voting rights, it is limited to the 
school environment and very few states give it. (Banner, 1984: 3).

Ronald L. Davis, a social observer, pointed out that there were social and cultural changes in the period of I 920s. He considered that a major change occurred because long-held values such as Puritanism experienced a shock with the emergence of new, highly materialistic values. Michael Spindler, a social observer, expressed his opinion about the social changes caused by economic prosperity in the 1920 s. In this case the middle class groups have the opportunity to get material that can improve their status and lifestyle to be higher. The emergence of "leisureclass" life raises its own problems in the life of the middle class.

The disintegration of traditional values recorded by novelists in his work is reflected in the behavioral and moral changes that shock American society. The most striking change was the emergence of a flapper (new woman) who wanted freedom with men both in the field of economics and political rights. Unwittingly during the war many women took over men's duties and they became increasingly aware of equal rights in all fields (Leuchtenburg, 1958: 159).

Other factors that encourage the emergence of flapper according to Frederick L. Allen are: (1) family life that has become more loose and provides many opportunities for women to be more independent in various ways, (2) Freud's teachings that develop among intellectuals 1 are not just theories but it is practiced in everyday life, (3) increasing use of cars as a common means for young people to be free to have sex, so that the car at that time was considered a "sinister place on wheels". The role of print, radio and film media is accelerating the spread of news about the appearance and behavior of women which are then copied by other women. If they do not follow the method at that time they will be considered old-fashioned and not modern. (Allen, 1938: 139-161). Dorothy M. Brown, a historian, stated that the old values that depressed women as guards of American morals faced challenges in the 1920s. All forms of old values change rapidly. Although their predecessor generation was very strict in instilling women's moral virtues, especially sexual problems which were considered taboo and inappropriate to be discussed in public. (Brown, 1987: 29-30).

Allen asserted that the freedom obtained, following the misinterpretation of Freud's teachings, made the younger generation, especially women, take advantage of this opportunity to give birth to the values of modern women. Their appearance has shown that they embrace values that are different from their predecessors. They are not shy about showing beauty of his body by wearing a short dress so that his body parts are visible, thin clothes that accentuate the curves of his body, wearing thick makeup. They also dare to smoke in public, drink liquor and even hold petting parties. If they want to have an influence on a man, he easily acts as a teaser at a dance party.

\section{RESEARCH METHODS}

The method used in this study is a qualitative approach which is a descriptive analysis approach. The type of research using in this paper is a qualitative descriptive. The qualitative descriptive research is one of the types of research included in this type of qualitative research. The purpose of this research is to reveal events or facts, circumstances, phenomena, variables and circumstances that occur when the research takes place by presenting what actually happened. This study interprets and describes the data concerned with the situation that is happening, the attitudes and views that occur in a society, the conflict between two or more states, the relationship between variables that arise, differences between facts that exist and their effects on a condition, and so on .

In brief, there are several steps in the descriptive research method, namely 1) Identifying the existence of significant problems to be solved through descriptive methods; 2) Limiting and formulating problems clearly; 3) Determine the objectives and benefits of the research; 4) conducting literature studies related to problems; 5) determine the framework of thinking and research questions and or research hypotheses; 6) designing research methods to be used including determining population, samples, sampling techniques, data collection instruments, and analyzing data; 7) collecting, organizing and analyzing data using relevant statistical techniques; and 8) make a research report.

\section{RESULTS AND DISCUSSION}

The appearance, behavior and morals of the flapper (new woman) at the beginning of his appearance had made a surprise at that time. The pro and contra resemble the opinions that emerged at that time. Many critics and social observers agreed and many criticized the flapper's ugliness. In connection with this problem, the author tries to analyze what is meant by flapper (new women), especially those shown by F. Scott Fitzgerald in his works.

In an interview with Fitzgerald, Bruccolli - a critic - cited Fitzgerald's opinion about a flapper. Fitzgerald classified flapper according to geographical origin into three categories: Middle West, Southerner girls, Easterner girls. A flapper who came from Middle West had an unattractive, selfish, arrogant, talking with a bad accent and he was not able to please a man. They also don't know exactly what they want, what is important for them is to get everything and not want to give anything. Often they are still bound by traditional boundaries. (Bruccolli, ed., 1974: 97).

Fitzgerald considered that among the three types of flapper, girls from South (Southerner girls) were the most interesting type of flapper in America. 
They maintain and even develop their ability to please men. Although they come from ordinary middle-class families and are not excessive in material problems, they still try to maintain the balance of social activities which certainly requires a high cost of living for it. Meanwhile the sophisticated Eastern girl is in the middle position of the two characteristics of the flapper (Middle West and South). When flapper from Middle West looks and behaves unattractively, then the South flapper has very interesting and beautiful-looking characteristics. So the flapper from East performed and behaved naturally, no less and not excessive.

The female figures in F. Scott Fitzgerald's works that will be discussed here are: Rosalind (This Side of Paradise), Daisy Fay and Jordan Baker (The Great Gatsby), and Nicole Warren and Rosemary Hoyt (Tender Is The Night) The five female figures mentioned above will be used as an example of a discussion that focuses on the characteristics analysis of flapper both physically and behavior and morally. In all three of Fitzgerald's work discussed below, the flapper figures shown were between 16 and 23 years old. The physical appearance of all the flapper in general is each described as a beautiful woman. Fitzgerald presents flapper figures as people who like to dress up. Flapper's style of makeup is trying to attract the attention of men to be lured to him. No wonder there is an impression of flapper behavior, but there are some of them described as having hair in bob. For example Nicole and Bernice, the main character of the short story (Bernice Bobs Her Hair) who deliberately cut her hair with a bob model. Meanwhile Fitzgerald only mentions other flapper characters with blond hair that is curly shoulder-length. Other characteristics of the flapper group are freedom of smoking and drinking alcohol in public (in the sense of one's own environment). Their behavior seems bold and ignores the previously prevailing norms about the very closed relationship between men and women. Life is full of luxury and their talk only revolves around superficial problems; for example about gossip and dance parties. There are no important problems they think about, especially those related to the development and development of the community.

The Victorian tradition places women as people who are fully responsible for the care and education of their children. As a housewife, Daisy is not a good mother's profile. He is not good at keeping his family. Childcare is given entirely to the maid. Eventhough he actually had a lot of time caring for his daughter. Most of his free time is spent in the interests of his satisfaction: dance parties, traveling, watching and so forth. This behavior is certainly very different from the Victorian tradition which requires women to be at home, caring for and educating their own children. The appearance of Daisy's child is only described in one event. And even then it was just a small talk for Gatsby to know that Daisy actually had children.

Other Victorian traditions mention that a mother is a "moral guiding" for her children. Daisy's attitude did not show that. He dreamed that his daughter would grow up to be a woman: "a beautiful little fool". This Daisy phrase implies a paradoxical meaning: the word "beautiful" and "fool". Beauty and at the same time this ignorance implies the state of the flapper itself. Perhaps this is the sarcasm that Fitzgerald made against the flapper group.

In presenting his characters, Fitzgerald used many elements of irony to emphasize the ugly character of the flapper figures. In addition, the element of irony is also used to criticize or even mock the behavior and moral values of flapper that harm others. The three main male characters who became flapper's husbands or husbands - Amory, Gatsby and Dick seemed unhappy and had been mistreated by flapper characters.

\section{CONCLUSION}

First. Evidenced by the similarity of the flapper characteristics described by social observers with the flapper figures that Fitzgerald displayed in his works. This equation is not absolute. There are general characteristics that are shown and there are also very distinctive characteristics. It is also seen that Fitzgerald as a whole does not overly emphasize the appearance of a flapper. He discussed more about the behavior and moral values adhered to by the parliament.

Second. The characteristics of flapper that were seen among the younger generation in the 1920s and also in all three of Fitzgerald's work showed a difference in the myths of true worship of female values. The difference in terms of appearance, behavior and moral values they have is very contradictory.

Third. The new values of flapper that emerged in the 1920 s developed among the younger generation of upper middle class women. The issue of new values is growing rapidly driven by print media that includes news, radio, TV and film and fiction reviews and works that reflect the situation of women in the 1920s. The momentary phenomenon shown this flapper is like "culture shock," because this situation was very shocking to American society at that time. The courage of self-actualization to display different behaviors gives rise to various opinions in society.

Fourth. Through his works, Fitzgerald criticized the life of a flapper full of "artificial" life. The appearance and behavior of flapper shows that they have artificial and insincere traits. Flapper is only concerned with life that is' full of falsehood and this is a lot of thinking about things that are superficial and meaningless.

The results of the analysis of Fitzgerald's works show that there are two paradoxical elements. His works on the one hand show the flapper's state of behavior and moral values in accordance with his era. But on the 
other hand indirectly from the point of character and characterization shows an implicit criticism of the social conditions of the time. Thus Fitzgerald could act as a reformer who was at the same time anti-reformist. He judged from one aspect of life that the flapper was pleasant, cheerful, full of freedom and the life of hedonism that women wanted. It turns out that the longevity of life is monotonous, boring, meaningless and does not even provide good values for the progress of the next generation.

\section{REFERENCES}

Allen, Frederick Lewis, 1938 ,Only Yesterday: An Informal History of The 1920's in America. London: Penguin Books.

Banks, Olive, 1981, Faces of Feminism : A Study of Feminism as a Social Movement. New York: St. Martin's Press.

Banner, Lois W.,1984, "Woman in Modern America: A Brief History. New York: Harcout Brace Jovanovich, Inc.

Brown, Dorothy M.,1987, American "HOmenin The 1920's: Setting a Course. Boston: Twayne Publisher.

Bruccoli, Matthew \& Bryer, Jackson R.,1971, F. Scott Fitzgerald: In His Own Time: A Miscellany. USA: The Kent State University Press

Budiman, Arief,1985, Pembagian Kerja Secara Seksual : Sebuah Pembahasan Sosiologis tentang Peran Wanita di dalam Masyarakat. Jakarta: P.T. Gramedia.

Chase, Richard, 1978, The American Novel and Its Tradition. New York: Gordion Press.

Davis, Ronald L.,1972, The Social and Cultural Life of th 1920s. New York: Holt Rinehart and Winston, Inc.

http://www.linguistikid.com/2016/09/pengertianpeneliti-deskcript-kualitative.html, downloaded on August 13, 2018.

https://idtesis.com/methods-descriptIFIC/ downloaded on August 13, 2018.

Levine, Lawrence W \& Middlekauff, Robert.,1972, The National Temper : Reading in American Culture of United States. USA: New York Harcoutt Brace Jovanovich, Inc

Ryan, Mary P.,1979, Wimanhood in American : From Colonial Times To The Present. New York: A Division of Franklin Watt

Spindler, Michael,1983, American Literature and Social Change. USA: Indiana University Press.

Showalter, Elaine.,1971, Wiman's Liberation and Literature. New York: Harcourt Brace Jovanovich, Inc.

Stavola, Thomas ,1989, F Scott Fitzgerald: Crisis in An American Identity. London : Clarke, Double \& Brenden Ltd. 